\title{
Review of physical methods in the treatment of Bell's palsy
}

\author{
Przeglad metod fizykalnych w terapii \\ porażenia nerwu twarzowego typu Bella
}

\begin{abstract}
Peripheral facial nerve damage is the most common condition of all cranial nerve damage; this nerve innervates the face in motor, sensory and parasympathetic ways. Bell's palsy prevents patients from functioning normally by disturbing the speech function, eating and facial expressions. It can also lead to severe inflammation of the eyeball and consequently to blindness. The study focuses on the influence of appropriately selected physical procedures on the time over which facial palsy affects a patient. The use of therapeutic methods such as: electrotherapy, heat treatment, facial massage, kinesitherapy and fillers were also presented

Comprehensive rehabilitation therapy based on the cooperation of doctors, physiotherapists and cosmetologists significantly improves the results of pharmacological treatment and shortens convalescence time.
\end{abstract}

Keywords: facial nerve, Bell's palsy, treatment

\section{STRESZCZENIE}

Obwodowe uszkodzenie nerwu twarzowego (który zaopatruje ruchowo, czuciowo oraz przywspółczulnie obszar twarzy) jest najczęstszym uszkodzeniem wśród nerwów czaszkowych. Porażenie typu Bella uniemożliwia osobom normalne funkcjonowanie poprzez zaburzenie funkcji mowy, spożywania pokarmów i mimiki twarzy. Może również prowadzić do ciężkich stanów zapalnych gałki ocznej, a w konsekwencji do utarty wzroku. W pracy zwrócono szczególną uwagę na wpływ odpowiednio dobranych zabiegów fizykalnych do okresu porażenia nerwu twarzowego. Przedstawiono zastosowanie metod terapeutycznych do których zalicza się: elektroterapię, leczenie ciepłem, masaż twarzy, kinezyterapię oraz zastosowanie wypełniaczy.

Kompleksowa terapia usprawniająca, oparta na współpracy lekarzy, fizjoterapeutów oraz kosmetologów znacząco poprawia wyniki leczenia farmakologicznego oraz skraca czas rekonwalescencji.

Słowa kluczowe: nerw twarzowy, porażenie typu Bella, leczenie

\section{INTRODUCTION}

The facial nerve is the VII cranial nerve in which the predominant motor fibers are for the muscles of the face and neck. Sensory fibers taste to the front $2 / 3$ of the tongue mucosa. Thanks to the parasympathetic fibers contained in this nerve, the secretory activity of the lacrimal gland, sub- mandibular and sublingual salivary glands, as well as small glands of the soft palate, mouth and nasal cavity is possible [1]. The nucleus of the facial nerve is located within the dorsal part of the bridge. The nerve comes out of the brain in the cerebellopontine angle. The muscles innervated by the VII cranial nerve include: the stylomastoid muscle, posteri- 
or abdominal muscle, levator palate and muscles responsible for facial expressions (eye, occipital frontal, cheek, levator of the upper lip and lower lip, chin and wide neck) ) [2].

The facial nerve can be damaged at the level of the brainstem, fibers inside and outside the skull. Its peripheral part, containing motor fibers responsible for the innervation of half of the face (monoplegia facialis), is most frequently affected [3].

\section{THE AIM OF THE STUDY}

The aim of the study was to develop a therapy model for people with Bell's facial nerve injury, as well as to show the anatomy and function of the VII cranial nerve and possible causes of its dysfunction. The possibility of assessing the undertaken therapeutic activities was also presented.

\section{CAUSES AND SYMPTOMS OF FACIAL NERVE PALSY}

One of the most common symptoms of paralysis is the dropping of the mouth corner, making it impossible to blow or whistle. It also hampers the ability to eat foods that can fall out of your mouth when you chew them and accumulate between the cheek and gums. It becomes impossible to close the eye and tearing is impaired. This can lead to inflammation and serious damage to the cornea. The forehead becomes smooth, without the possibility of wrinkling. There is also a loss of deep feeling in the face area (fig. 1) [4].

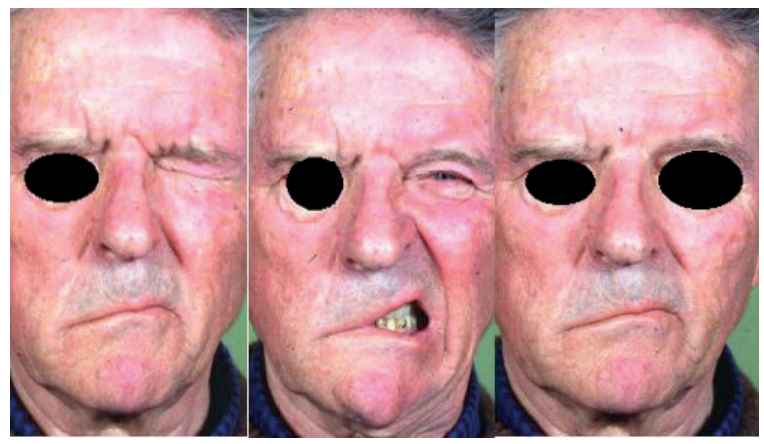

Fig. 1 Male with damage to the peripheral part of the facial nerve Source: Author's own archive

The causes of facial nerve palsy can be seen at different levels: central, peripheral and secondary. Central causes include the consequences of stroke, as well as tumors in its area. Injury may be one of the symptoms of multiple sclerosis and inflammatory processes in the cranial cavity. Most often, however, paralysis occurs in the peripheral part in an idiopathic manner, it is called Bell's palsy. The causes are not fully understood, although there are assumptions about its viral etiology (herpes virus). Peripherally, the nerve may be involved in the course of neurobolerosis, as well as in
Ramsay Hunt syndrome (the herpes zoster, in which the facial nerve knee ganglion is affected, may also involve impaired hearing) [5]. In many disease entities it is possible to recognize concomitant damage to the VII cranial nerve. These include hormonal disorders, such as diabetes and hypothyroidism, as well as autoimmune diseases (Guillain-Barré syndrome, Moebius syndrome, systemic lupus or myasthenia gravis) [6]. One should also not forget about the paralytic effects of inflammation within the middle ear, the top of the cortical bone pyramid and the mastoid part of the temporal bone. A tumor of the sternocerebellar angle may compress the nerve as it exits the brain. Other neoplastic diseases, such as leukemia, meningeal carcinoma or lymphoma, also tend to influence the disturbances in the flow of electrical impulses in this nerve [5].

Facial nerve damage may also occur as a complication of aesthetic procedures:

- HIFU (high-intensity focused ultrasound) - a treatment used to lift the face, uses a focused beam of sound waves with a large range [7],

- injection of botulinum toxin [8].

Bell's palsy is characterized by an isolated acute onset of the motor neuron of the facial nerve, usually unilaterally weakening. It is estimated that annually from 11 to 40 cases of this paralysis per 100,000 people worldwide [9], it is more common in diabetic patients than in the healthy population [10]. There are several possible etiologies of Bell's palsy: viral (herpes simplex virus), inflammatory, autoimmune and vascular.

The most common symptoms in most patients on the side of the injured nerve are the disappearance of frontal wrinkles and smoothing the skin. There is also drooping of the eyelid, increased lacrimation or, on the contrary, dryness of the eye. Facial muscles can be paralyzed (muscle strength on the Lovette scale 0-1) or paralysis (strength 1-3). The corner of the mouth is dropped, patients may report dry mouth and taste disturbances. The diagnosis of Bell's palsy is made mainly on the basis of clinical symptoms [9].

Drooping eyelid often causes the eye to dry out and become inflamed. For this reason, it is important to protect them against loss of moisture, e.g. by using gauze compresses soaked in saline. In the current, international literature, pharmacological therapy is under discussion because in $70 \%$ of patients the normal function of the facial nerve returns without its implementation [10]. Drugs used in this case include corticosteroids and antiviral drugs.

The paralysis of the facial nerve has three stages.

1. The period of flaccid muscle paralysis (fig. 2) 


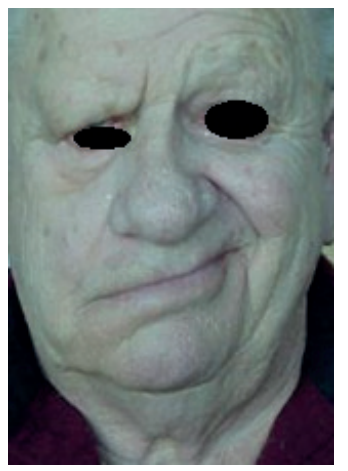

Fig. 2 A man with flaccid facial muscles paralysis Source: Authors' own archive

2. The period of muscle paresis (fig. 3). This is the period of paralysis regression and improvement in muscle tone. Movements of the paresis muscles begin to be visible. During this time, symmetrical exercises should be used, isolated on the side of paresis. The patient should be secured against the occurrence of co-movements.

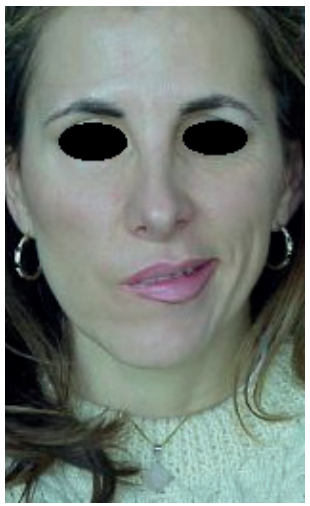

Fig. 3 Woman with facial muscles paresis Source: Authors' own archive

3. The period of facial muscles coexistence (fig. 4). Increased tension of the paresis muscles is observed, their movement patterns are abnormal [4]. Stretching exercises and inhibition of the rests are recommended.

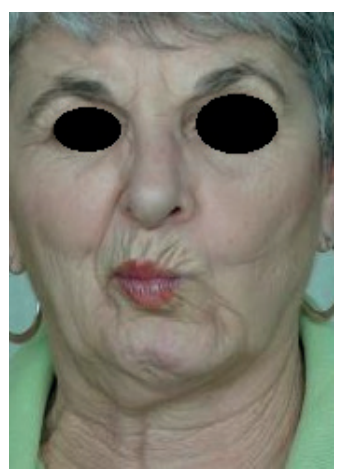

Fig. 4 Woman with facial muscles coexistence Source: Authors' own archive

\section{TREATMENTS IN BELL'S PALSY TYPE THERAPY}

The basis of the therapy is the use of exercises in the field of kinesiotherapy and physical procedures adapted to the period of the disease [11]. It is recommended to exercise the facial muscles on the side of paresis: the cheek muscle - blowing soap bubbles, the frontal muscle - wrinkling the forehead. Cosmetic massage of the face and pressure on sore spots (trigger points) can also be helpful [12]. In the case of physical treatments, it is recommended to irradiate the Sollux lamp with a red filter, brush the face with paraffin or mud paste [13-15].

The most common electrotherapeutic procedures are anodic galvanization with an analgesic effect and electrostimulation with the use of exponential currents - the type of stimulation used in the stimulation should be matched to the strength of the cheek muscle [16].

Nerve regeneration progresses faster when applying warm compresses (dry heat, eg wool compresses, hot water bottle) [17]. Remember to properly protect the eyeball against the formation of ulceration of the cornea due to its drying out.

\section{Kinesiotherapy}

It includes exercises of the facial muscles on both the damaged side and the healthy side to improve the reception of stimuli in representative areas of the cerebral cortex. Exercises should be performed in front of a mirror, initially under the supervision of a therapist. Exercise the facial muscles three times a day, starting from 15 minutes to 20 minutes. The muscle contraction time per repetition should be 10 seconds. Relaxing exercises, the so-called consciously relaxing the facial muscles. Before the exercises, you can apply facial overheating on the side of paresis using a Solux lamp with a red filter at a distance of about $50 \mathrm{~cm}$. The red filter ensures deeper penetration of the visible and infrared light waves, which contributes to the improvement of blood supply. The duration of a single treatment should last 10 minutes. Instead of irradiation, you can use a mask or paraffin brushing for about 30 minutes. A series of overheating treatments should include twenty treatments performed every day or every other day $[18,19]$.

\section{Electrotherapy}

Treatments with the use of galvanic current can be used in the number of 20 repetitions, after which a 10-day break is indicated. After that, it is possible to start another series until facial muscle function returns. Iontophoresis with vitamin B1 at a concentration of 2-5\% and iontophoresis with $1-2 \%$ calcium chloride, administered from under the positive electrode, complement the pharmacological treatment. Before performing the procedure with vitamin B1, it should be checked whether there is any allergy to it $[18,20]$. 


\section{Face massage}

It is recommended to perform a classic massage on both sides, which includes rubbing, stroking, patting and carefully kneading. Remember to start and end the treatment with stroking. The places that should be worked out are the eyebrows, cheeks, circular muscle of the mouth and eye, chin and forehead. Massage should not be performed in the acute period, when there is hyperaesthesia and facial pain. The series may include 10 to 20 treatments [21].

\section{Gel with hyaluronic acid and lidocaine}

In people who have regurgitation of the eyelids that do not qualify for surgery, the use of a gel with hyaluronic acid and lidocaine is helpful. The best results are obtained by using a preparation with a combination of low and high molecular weight hyaluronic acid with a lower concentration and high level of cross-linking. It is applied with a 30G needle giving small amounts of the preparation along the entire length of the upper eyelid (about 20 injections). Deep punctures in the area of the aponeurosis of the circular muscle should be performed to avoid superficial and excessive gel deposition in any single area [22].

\section{Botulinum toxin}

Injecting the buccal muscle with botulinum toxin can help to silence the synkinesis that develop during the period of muscle paresis [23]. It is also possible to administer this preparation to other facial muscles on the side of the damaged nerve, e.g. the broad neck muscle, or the circular muscle of the eye. It should be remembered that the patient may experience increased pain sensations. It is suggested to use gels with analgesics and fine needles (30G), as well as preparations containing botulinum toxin type A [24, 25].

\section{Hyaluronic acid for injection}

In order to restore the symmetry of the face, at the beginning, the application of hyaluronic acid preparation can be used in the area of nasolabial furrows, marionette lines, lips. A larger amount of the product should be injected into the unaffected half of the face to obtain the appropriate, aesthetic proportions [25].

\section{Preparations stimulating the production of collagen} During subsequent visits, it is recommended to use a filling preparation that will stimulate collagen production. In this case, L-polylactic acid will work well. Sometimes it is necessary to perform treatments that will help restore the oval of the face. Injecting the cheeks, nasolabial furrow or puppet line with calcium hydroxyapatite will have a strong stimulating effect on the natural production of this ingredient $[25,26]$.
Before starting the treatments, discuss the expected effects, and emphasize the fact that they will not be visible immediately. It will be necessary to repeat the procedures several times using different preparations, which is caused by the specificity of the phased course of the facial nerve palsy [27].

\section{EVALUATION OF TREATMENT OUTCOMES}

Evaluation of treatment results can be based on House and Brackmann's classification of facial nerve function, which allows the degree of damage to be assessed and the regeneration process to be followed. There are six degrees of nerve damage [28].

- I - correct activity. All facial muscles function properly.

- II - slight paresis. Correct symmetry and tension at rest, complete closure of the eye with little effort, slight asymmetry of the mouth.

- III - moderate paresis. Visible asymmetry of the sides during movements, there are synkinesis, contractures or hemispasm of the face, symmetry is preserved at rest, impaired activity of the forehead muscles, complete closure of the eye with effort, mouth asymmetry during movements.

- IV - significant paresis. Visible asymmetry with movements, symmetry and tension at rest, no forehead muscle movements, eyelid gap not closing, lip asymmetry even with maximum effort.

- $\mathrm{V}$ - severe paresis. Trace movements, asymmetry of the face at rest, no movement of the forehead muscles, regurgitation of the eye fissure, trace lip movements.

- VI - complete paralysis. No moves.

\section{SUMMARY}

Bell-type facial nerve damage is both a medical and cosmetic problem. The Toronto facial nerve injury treatment center uses a similar model to that implemented in Polish centers [22]. In order to accelerate the recovery of nerve function, kinesiotherapeutic exercises are used, including facial muscle exercises, heat treatment and electrical stimulation. The authors also emphasize the significant role of psychological support for the patient due to the changed face aesthetics and the earliest possible initiation of specialist therapy [29].

According to randomized studies conducted by Murthy, the use of pharmacotherapy in the form of prednisolone significantly improves treatment results and shortens the recovery time [30]. The use of facial muscle exercises in acute cases of Bell's palsy prevents the formation of later synkinesis after exercise [31]. During the therapy, aesthetic procedures, such as the application of gels and injections with hyaluronic acid and botulinum toxin, are also helpful [22-25]. 
However, the observations of some authors show that, despite treatment, in approximately $30 \%$ of patients, permanent, mild injuries of the facial nerve persist, manifested by weakening of the mimic facial muscles [32]. In these cases, it is possible to improve the appearance of the face by performing treatments based on the use of fillers that simultaneously stimulate the natural production of collagen. They include, among others L-polylactic acid and calcium hydroxyapatite [25].

In the treatment of Bellla facial nerve injuries, pharmacotherapy and comprehensive rehabilitation treatment are used, taking into account the patient's education in terms of proper exercise and the use of selected physiotherapeutic treatments. Cosmetic treatments and appropriate care support the effects of therapy. Assessment of treatment outcomes may be based on the House and Brackmann scale.

\section{REFERENCES / LITERATURA}

1. Bochenek A, Reicher M. Układ nerwowy obwodowy. Układ nerwowy autonomiczny. In: Anatomia cztowieka. T. 5. Warszawa: Wyd. PZWL; 1989:212-221.

2. Holland NJ, Weiner GM. Recent developments in Bell's palsy. BMJ: British Medical Journal. 2004;329(7465):553-557.

3. Kozubski W, Liberski PP. Choroby uktadu nerwowego. Warszawa: Wyd. PZWL; 2004:319-322.

4. Medscape. www.emedicine.medscape.com/article/1290547-overview. Accessed 25.08.2020

5. Sienkiewicz-Jarosz H. Nerw twarzowy - fizjologia i najczęstsze choroby. Neurologia po Dyplomie. 2013;8(2):52-57.

6. Newadkar UR, Chaudhari L, Khalekar YK. Facial Palsy, a Disorder Belonging to Influential Neurological Dynasty: Review of Literature. $N$ Am J Med Sci. 2016;8(7):263-267. doi:10.4103/1947-2714.187130. Accessed 25.08.2020.

7. Sathawoeawong A, Wanitphakdeedecha R. Nerve injury associated with high-intensity focused ultrasound: A case report. J Cosmet Dermatol. 2018;17(2):162-164.

8. Hisashi I, Shigeru F, Tetsumasa K. Facial Nerve Palsy after Botulinum Toxin Therapy for Hemifacial Spasm: A Case Report. J Neurol Neurosci. 2018;9(3):257. doi:10.21767/2171-6625.1000257. Accessed 25.08.2020.

9. Zhao Y, Feng G, Gao Z. Advances in diagnosis and non-surgical treatment of Bell's palsy. J Otol. 2015;10(1):7-12. doi:10.1016/j.joto.2015.02.003. Accessed 20.08.2020.

10. De Diego-Sastre JI, Prim-Espada MP, Fernández-García F. The epidemiology of Bell's palsy. Rev Neurol. 2005;4:287-290. doi:10.3399/bjgp13X663262. Accessed 20.08.2020.

11. Mosforth J, Taverner D. Physiotherapy for Bell's palsy. Br Med J. 1958;2(5097):675677. doi:10.1136/bmj.2.5097.675. Accessed 22.08.2020.
12. Li P, Qiu T, Qin C. Efficacy of Acupuncture for Bell's Palsy: A Systematic Review and Meta-Analysis of Randomized Controlled Trials. PLoS One. 2015;10(5):e0121880. Published 2015 May 14. doi:10.1371/journal.pone.0121880. Accessed 22.08.2020. 13. Guan L, Li G, Yang Y, et al. Infrared thermography and meridian-effect evidence and explanation in Bell's palsy patients treated by moxibustion at the Hegu (LI4) acupoint: Overall regulation or a specific target? Neural Regen Res. 2012;7(9):680685. doi:10.3969/j.issn.1673-5374.2012.09.007. Accessed 22.08.2020.

14. Ordahan B, Karahan AY. Role of low-level laser therapy added to facial expression exercises in patients with idiopathic facial (Bell's) palsy. Lasers Med Sci. 2017 32(4):931-936. doi: 10.1007/s10103-017-2195-9. Accessed 22.08.2020.

15. Włudyka B. Piękno i zdrowie czerpane z ziemi. Cabines Polska. 2011;45:12-15.

16. Somasundara D, Sullivan F. Management of Bell's palsy. Aust Prescr. 2017;40(3): 94-97.

17. Shafshak TS. The treatment of facial palsy from the point of view of physical and rehabilitation medicine. Eura Medicophys. 2006;42(1):41-47.

18. Straburzyński G, Straburzyńska-Lupa A. Fizjoterapia. Warszawa: PZWL; 2003.

19. Mika T, Kasprzak W. Fizykoterapia. Warszawa: PZWL; 2013.

20. Edwards S. Neurological Physiotherapy. A problem solving approach. Edinburgh: Churchill Livingstone; 2002.

21. Lewandowski G. Masaż leczniczy. Łódź; Annał; 2012.

22. Mancini R, Taban M, Lowinger A, et al. Use of hyaluronic Acid gel in the management of paralytic lagophthalmos: the hyaluronic Acid gel „gold weight“. Ophthalmic Plast Reconstr Surg. 2009;25(1):23-26. doi:10.1097/IOP.0b013e318192568d. Accessed 20.08.2020.

23. Cooper L, Lui M, Nduka C. Botulinum toxin treatment for facial palsy: A systematic review. J Plast Reconstr Aesthet Surg. 2017;70(6):833-841. doi:10.1016/j. bjps.2017.01.009. Accessed 20.08.2020.

24. Thien C, Santos Steffen M, Novaes Fernandes M, et al. Botulinum toxin in the treatment of sequelae of facial palsy: dermatologist's practice. Surg Cosmet Dermatol. 2019;11(3):238-243

25. Wiener A, Touloei K, Glick BP. A Novel Long-term Therapy of Facial Synkinesis with Botulinum Neurotoxins Type A and Fillers. J Clin Aesthet Dermatol. 2011;4(3):45-49.

26. Santoro M, Shah SR, Walker JL, Mikos AG. Poly(lactic acid) nanofibrous scaffolds for tissue engineering. Adv Drug Deliv Rev. 2016;107:206-212. doi:10.1016/j. addr.2016.04.019. Accessed: 20.07.2020.

27. Heckmann JG, Urban PP, Pitz S, et al. The Diagnosis and Treatment of Idiopathic Facial Paresis (Bell's Palsy). Dtsch Arztebl Int. 2019;116(41):692-702. doi:10.3238/ arztebl.2019.0692. Accessed: 20.07.2020.

28. House JW, Brackmann DE. Facial nerve grading system. Otolaryngol Head Neck Surg. 1985;93(2):146-147.

29. Finsterer J. Management of peripheral facial nerve palsy. Eur Arch Otorhinolaryngol. 2008;265(7):743-752.

30. Murthy JM, Saxena AB. Bell's palsy. Treatment guidelines. Ann Indian Acad Neurol. 2011;14(1):70-72

31. Teixeira LJ, Valbuza JS, Prado GF. Physical therapy for Bell's palsy (idiopathic facial paralysis). Cochrane Database Syst Rev. 2011;7(12):CD006283. doi:10.1002/14651858.CD006283.pub3. Accessed 25.08.2020.

32. Holland NJ, Bernstein JM. Bell's palsy. BMJ Clin Evid. 2014;2014:1204. 